\title{
Do mito ao voo: a metamorfose da simbologia mítica nos super-heróis
}

\author{
Marcio Cappelli Aló Lopes* \\ Vitor Chaves de Souza**
}

\section{Resumo}

O artigo procurará desenvolver uma reflexão hermenêutica a respeito da preservação de aspectos míticos nos super-heróis. Para isso, recorre a referenciais da teoria literária e ciências da religião. Parte-se da necessidade existencial por narrativas, trabalha-se com Umberto Eco para elaborar uma noção simbólica incônscia e termina com Mircea Eliade para prolongar a temporalidade dos perfis heroicos enquanto elemento mais atual e original do papel das personagens na vida dos leitores e espectadores. A intenção da pesquisa não é desenvolver todos os aspectos míticos nem analisar nominalmente uma variedade de personagens, mas relacionar símbolo e tempo como uma das expressões mais próprias do perfil do super-herói na interface HQ e religião.

Palavras-chave: Super-herói. Mitologia. Literatura. Simbolização incônscia. Temporalidade.

\section{From myth to super-flight: the mythic symbology metamorphosis in superheroes}

\begin{abstract}
The article develops a hermeneutic reflection on the preservation of mythical aspects in superheroes. References on literary theory and the sciences of religion are gathered to analyze an existential need for narratives; also, Umberto Eco's works on unconscious symbolization and Mircea Eliade's temporality are mainly focused as a special and original element of superheroes role in the lives of readers and spectators. The intention of the research is not to develop all the mythical aspects nor to analyze characters variety, but to relate symbol and time as one of the most appropriate superhero expressions in the interface between comic books and religion.
\end{abstract}

Keywords: Superhero. Mythology. Literature. Unconscious symbolization. Temporality.

\footnotetext{
* Doutor em Teologia (Puc-Rio); professor do PPG em Ciências da Religião da Universidade Metodista de São Paulo. E-mail: marcio.lopes@metodista.br

** Doutor Ciências da Religião (UMESP); professor do PPG em Ciências da Religião da Universidade Metodista de São Paulo. E-mail: vitor.chaves@metodista.br
} 


\section{Del mito al vuelo: la metamorfosis del simbolismo mítico en los superhéroes}

\section{Resumen}

El artículo buscará desarrollar una reflexión hermenéutica sobre la preservación de los aspectos míticos en los superhéroes. Para ello, utiliza las referencias de la teoría literaria y las ciencias religiosas. Se aparta de la necesidad existencial de narraciones, trabaja con Umberto Eco para elaborar una noción simbólica inconsciente y termina con Mircea Eliade para prolongar la temporalidad de los perfiles heroicos como el elemento más actual y original del papel de los personajes en la vida de los lectores y espectadores. La intención de la investigación no es desarrollar todos los aspectos míticos ni analizar nominalmente una variedad de personajes, sino relacionar el símbolo y el tiempo como una de las expresiones más apropiadas del perfil de superhéroe en la interfaz y la religión del cómic.

Palabras clave: Superhéroe. Mitología literatura. Simbolización inconsciente. Temporalidad.

\section{Introdução}

A história das religiões, pelo método comparativo da escola de Chicago, resgata uma variedade infindável de narrativas, ideias e crenças a respeito da condição humana arcaica. Trabalhos antropológicos e tipológicos demonstram um alcance superior às estruturas de conteúdos desprendidos das margens estreitas dos dogmas. Diante disso, é possível trabalhar a preservação dessas estruturas - bem como, as suas variações - em outras narrativas isentas de qualquer confessionalidade sagrada. Eis o interesse desta pesquisa: verificar a sobrevivência de arquétipos sagrados nas figuras dos super-heróis do século XX. O trabalho dispensará temas como a origem, a corporeidade e a história dos super-heróis. Interessa-nos, aqui, a aproximação entre mitologia e religião, a saber: os traços míticos preservados nos super-heróis, enquanto categorias artísticas e culturais, e a correspondência de temas com estruturas religiosas. Parte-se da hipótese de que os super-heróis preservam e camuflam elementos míticos e sacros, mesmo se laicizados em seus enredos. Muitas virtudes já foram apontadas por especialistas no assunto, ${ }^{1}$ entretanto, para além das questões sociais, de preconceito e tolerância, há outros horizontes, principalmente comuns, na composição dos super-heróis enquanto personagens. É essa composição que nos interessa, aliás, não apenas aquilo que os super-heróis significam - ou podem significar - mas o alicerce que são construídos.

\footnotetext{
1 Para uma boa introdução ao assunto, conferir: Para o alto e avante: uma análise do universo criativo dos super-heróis (REBLIN, 2008).
} 
Para efeitos didáticos, quando nos referirmos aos super-heróis modernos, de modo geral, nos contentaremos com o personagem Superman, ${ }^{2}$ uma vez que, filosoficamente, outros personagens seriam apenas, conforme Umberto Eco, outra variação do tema de superpoderes. Evidentemente, dispensamos também a figura antagônica dos heróis, i.e., os vilões, uma vez que, dada a variedade de possibilidades do mal, o estudo do papel e da função do vilão promoveria uma ambiguidade fraccionada na reflexão original. A natureza quebrada do vilão pediria, a nosso ver, por outra simbólica de estudo, de modo que a reflexão do super-herói, neste caso, nos seria suficiente para uma elaboração hermenêutica dos perfis sagrados e seus significados preservados nos temas, tramas e representações heroicas laicizadas.

Afinal, segundo Mircea Eliade, "os personagens dos comic strips (histórias em quadrinhos) apresentam a versão moderna dos heróis mitológicos ou folclóricos" (ELIADE, 2006, p. 159). Tal atestação é original do autor e inusitada, sobretudo pela formalidade de sua carreira na história das religiões. De fato, essa afirmação de Eliade motivou a pesquisa e, ao mesmo tempo, devido a própria originalidade do trabalho eliadiano na escola de Chicago, inspirou-nos no recorte interpretativo dessa nova versão moderna dos heróis. Diversas pesquisas se dedicaram ao fenômeno das estruturas míticas sobreviventes em personagens como os super-heróis. Com efeito, The Comics (1947) de Coulton Waugh, Comic Art in America (1970), de Stephen Backer, e Il Mito di Superman (1962), de Umberto Eco, se destacam entre as obras pioneiras. É certo que Peter Coogan também situou a mitologia no nascimento dos super-heróis. Eliade não foi o primeiro a fazer tal observação. Entretanto, a novidade de Eliade reside em uma interpretação fenomenológica do perfil heroico - o fenômeno do super-herói como um todo, irredutível às outras acepções, original em sua manifestação mítica -, identificando estruturas comuns internas entre as personagens heroicas míticas e modernas, bem como, os traços característicos de Superman em estruturas externas. Tal artigo, portanto, interessa-se por essas manifestações e estruturas internas e externas do personagem e se apresenta como um exercício fenomenológico

2 Neste artigo, respeitando as devidas terminologias, serão usados Superman para se referir ao personagem criado pelo escritor Jerry Siegel e o desenhista Joe Shuster, propriedade intelectual da DC Comics, e super-homem para se referir a qualquer noção mítica de um ser humano com poderes supernaturais ou potências filosóficas do Übermensch, de Friedrich Nietzsche. Para uma análise detalhada sobre o Super-Homem, bomo superior e Übermensch, cf. o capítulo 6, "The Prehistory of the Superhero: The Antediluvian Age" (COOGAN, 2006). 
a partir de um teórico da área das Ciências da Religião, Mircea Eliade reconhecido pelo seu trabalho com filosofia da religião e cultura popular - agora, trabalhando um de seus temas mais marginais e inusitados: a simbolização e a superação pelos super-heróis.

\section{Do mito ao voo: aproximações mitológicas e criações imaginárias}

Muito já foi dito sobre a migração dos mitos para a literatura e até mesmo que as formas literárias não passam de variações dos mitos (FRYE, 2004). De fato, é possível perceber as ressonâncias da mitologia na literatura moderna e contemporânea. Sem entrarmos na discussão sobre se as HQs cabem na designação de literatura - até porque hoje não há uma distinção clara do que o termo literatura possa significar ${ }^{3}-$, admitiremos que elas, assim como as suas adaptações em telas de TV e cinema - que a princípio, serão aqui assumidas em igualdade, uma vez que os meios de divulgação não diferenciam o gênero da superaventura ${ }^{4}-$, tratam de aventuras modernas e atuais de temas antigos e clássicos. Pressupõe-se, em primeiro lugar, as preservações de estruturas arcaicas nas narrativas modernas, a despeito da crítica da arte. Discussões como se histórias em quadrinhos são ou não arte, se há por detrás delas uma visão elitista ou se o destino das “estórias" reside numa crítica social em dizeres alegóricos, apesar de serem discussões legítimas, tanto da crítica à arte como da sociologia, são deixadas de lado para dar voz ao fenômeno das personagens enquanto uma forma de dizer do que é mais próprio do humano. Trata-se de uma pressuposição hermenêutica ressoante com a pressuposição inicial: estruturas arcaicas presentes nas narrativas modernas, em forma de superaventura, ressignificariam em outra linguagem o abandono religioso por parte do indivíduo secularizado.

Toda a problemática que envolve a definição de "literatura" é ampla e complexa. "Tem havido a tendência, cada vez maior, de derrubar barreiras divisórias, em uma perspectiva pragmática, considerando que o próprio cânon é estabelecido acima de tudo pela sociedade. A diluição cada vez maior dos gêneros literários clássicos igualmente contribui para esse estado de coisas. Qualquer produção cultural: um romance, um texto histórico, um diário, sermões, ou mesmo a letra de uma música funk, é considerada literatura" (FERREIRA, 2008, p. 9).

4 Partimos da ideia de Benjamin a respeito dos modos de produção da arte nos dias atuais: "Seria impossível dizer, de modo geral, que as técnicas de reprodução separam o objeto reproduzido do âmbito da tradição” (Cf. BENJAMIM, 1983, p. 8). 
A intenção do recorte reside, ainda, no fato de analisar o heroísmo como elemento comum do elo entre leitor e/ou espectador e trama narrativa da aventura para além de uma compreensão monomítica da jornada do herói. O monomito clássico de Ulisses ou Moisés, com o chamado à aventura e as doze etapas da jornada do herói, diz mais respeito à introdução das personagens no mundo do que sobre o próprio herói em si. A motivação do herói é ser reconhecido socialmente pelos seus feitos e se reintegrar à sociedade. Já os super-heróis, devido à sua condição fantástica - e moderna -, se distinguem pela origem peculiar, fantástica, mas não religiosa, com motivações puras, tarefas nobres e obrigações redentoras tendo, principalmente, poderes extraordinários. O super-herói, geralmente, se origina fora da comunidade - é um estrangeiro ou alienígena - e é chamado para salvar a comunidade (JEWETT; LAWRENCE, 2002, p. 47-48). Ele é um solitário ideal e, assim sendo, se diferencia discretamente do herói do monomito tradicional, uma vez que a sua aventura não teria, a rigor, um compromisso com um ciclo de tradição e redenção comunitária. Afinal, assim como pode ser argumentado que todo super-herói representa o monomito, nem todos heróis monomíticos se encaixariam, por definição, no perfil do super-herói, de modo que o diferencial do super-herói par excellence estaria na sua significação simbólica - característica não compartilhada com todos os heróis monomíticos (cf. MIETTINEN, 2011, p. 16).

A Proto-Era ${ }^{5}$ dos super-heróis remete à mitologia e outras narrativas fundantes como solo criativo da elaboração super-heroica. Jerry Siegel, um dos criadores do Superman, escreveu a respeito da influência dos mitos na composição do Superman: "De repente, eu percebi. Eu concebi um personagem como Sansão, como Hércules e todos os demais homens fortes que eu ouvi falar em um só personagem. Nada mais" (SIEGEL apud COOGAN, 2006, p. 117). ${ }^{6}$ Peter Coogan dedica um capítulo em seu livro Superhero ao tema das raízes mitológicas dos super-heróis e, nessa obra, destaca a importância da

\footnotetext{
5 "Before that preliminary point, only the primordial "roots" of a genre can be traced, but after that certain point and for a significant period of time the initial prototypes of a genre's conventions coalesce and are a part of other narrative forms and story genres. I designate the period before this point as the Proto Age; the myths, legends, and epics of this period serve as the roots for all the adventure metagenres and contain the prototypes of all the heroes of the adventure meta-genre" (COOGAN, 2006, p. 116).

6 "All of a sudden it hits me. I conceive of a character like Samson, Hercules, and all the strong men I ever heard of rolled into one. Only more so" (SIEGEL apud COOGAN, 2006, p. 117).
} 
Proto-Era na formulação das narrativas de heróis modernos. Entre algumas histórias marcantes, faz-se notar a possibilidade do encontro de elementos típicos dos super-heróis atuais nas histórias mais antigas, por exemplo, a epopeia de Gilgamesh. ${ }^{7}$ A aventura de Gilgamesh contém diversas tramas características do mundo dos heróis, como a sua má administração de Uruk, o castigo dos deuses, a queda e a reconciliação com Enkidu - uma espécie de sidekick -, antes um monstro aterrorizante, agora companheiro de Gilgamesh, para os chamados das aventuras. Enkidu o serve como ajudante, assim como Pátroclo para Aquiles, Iolaus e Hylas para Hércules e Robin para Batman. A recusa do casamento com Ishtar - um ponto de tensão e virada na epopeia - se assemelha à renúncia da tentação sexual, algo como um celibato heroico de muitos superheróis, denotando um estilo de vida diferenciado da sociedade (JEWETT; LAWRENCE, 1977, p. 31). Ele também busca poder para transcender o mundo mortal. Os superpoderes dos super-heróis violam as leis naturais, assim como Gilgamesh procura violar a lei da mortalidade buscando a imortalidade. "Por toda a eternidade a tábua nunca mudará. Por toda eternidade o aprendizado nunca terminará" (GEORGE, 1999, p. XIII), registra um poema sumério de Shulgi B a respeito da epopeia de Gilgamesh: se o protagonista não alcançou a imortalidade carnal, a sua epopeia permanecerá imutável pela eternidade, elaborando e preservando algumas virtudes heroicas, como a liberdade diante das limitações da vida humana. O exemplo de Gilgamesh, sendo a mais antiga narrativa elaborada e preservada da qual se tem registro, ilustra a aproximação do monomito heroico entre narrativas antigas e "estórias" de super-heróis. Tal diálogo permite um tipo de gênero próprio, já mencionado, o da superaventura.

Iuri Reblin, autor da tese doutoral sobre histórias em quadrinhos $A$ superaventura: da narratividade e sua expressividade à sua potencialidade teológica - que, vale ressaltar, recebeu o Prêmio Capes de Tese na área de Teologia, subcomissão da área Filosofia/Teologia, em 2013 -, ao comentar a respeito do perfil dos super-heróis, os poderes extraordinários dos super-heróis e do universo dualista no qual se encontram, propõe um gênero literário denominado por superaventura (REBLIN, 2008, p. 23). A dualidade é interior e exterior ao personagem, uma vez que ele pode ser amado ou temido, bem como, o seu mundo apresentaria dualidades próprias. Ao comentar acerca da referência de Eliade ao Superman, Iuri Reblin retoma os anseios humanos no surgimento dos super-heróis, cujo desejo busca a transcendência das próprias barreiras existenciais, os limites do

\footnotetext{
Recomenda-se, aos interessados, a leitura da brilhante tradução de Jacyntho Lins Brandão (SIN-LÉQI-UNNÍNNI, 2017).
} 
mundo e a superação dos problemas físicos e imediatos (REBLIN, 2008, p. 41). O herói representaria, para o público geral e os fãs, a possibilidade de as aspirações e crenças humanas em ideais. De certa forma, a identidade do leitor e/ou espectador se reflete no heroísmo.

Inicialmente, pode soar rasa a leitura de um super-herói ser uma possibilidade de conhecimento e reconhecimento humano - de fato, a origem dos super-heróis, em sua natureza diversificada e distinta, promove a imaginação perene e percepção de possiblidades pela fantasia inconscientemente num processo consciente de produção cultural (cf. VIANA, 2005, p. 61). O conhecimento humano se manifesta pela criatividade diurna de um processo necessário às potencialidades reprimidas. $\mathrm{O}$ mundo onírico e fantástico, segundo uma perspectiva hermenêutica da religião, prolonga os desejos primordiais e os anseios existenciais do ser humano - ou, se preferirmos, do homo religiosus (ELIADE, 2002, p. 61). O super-herói nasce na mesma irredutibilidade da narrativa presente, de uma forma readaptada na consciência moderna. Com a recepção e apreciação das HQs, filmes de super-heróis e outros formatos das personagens, ${ }^{8}$ a despeito da crítica da indústria cultura de Adorno, firma-se que o indivíduo atual, como o homem das sociedades arcaicas, "não pode existir sem mitos, sem estórias exemplares" (ELIADE, 1990, p. 150). ' Há uma necessidade existencial para narrativas, mitos e sonhos, que é praticamente orgânica. Nessa necessidade, situamos não apenas os perfis míticos, mas também a literatura, dada a condição humana da linguagem e da criação mimética para a expressão de valores e anseios. Pois “os universos imaginários criados nas novelas, estórias e contos revelam certos valores e significados únicos para a condição humana que, sem tais narrativas, ficariam desconhecidos ou, pelo menos, compreendidos imperfeitamente" (ELIADE, 1989, p. 283). ${ }^{10} \mathrm{O}$ teólogo Adolphe Gesché parece reforçar essa ideia quando sublinha:

\footnotetext{
8 Para mais informações sobre o processo de criação, divulgação e apreciação de HQs, sobretudo a rentabilidade promovida pela comercialização dessas marcas e ideais, bem como, a variedade de uso das personagens pela indústria cultural, cf. Ducan, Randy. Smith, Matthew. The Power of Comics: History, Form and Culture. New York: The Continuum Publishing Company, 2009.

9 "Modern man, like the man of archaic societies, cannot exist without myths, without exemplary stories" (ELIADE, 1990, p. 150).

10 "The imaginary universes created in novels, stories, and tales reveal certain values and meanings unique to the human condition which, without them, would remain unknown, or, at the very least, imperfectly understood" (ELIADE, 1989, p. 283).
} 
O imaginário é um desses lugares no qual ele [o ser humano] procura compreender-se e dar sentido a sua existência. O imaginário é aquele de toda uma tradição onde ele se enraíza, feita de mitos, de contos e de lendas. (...) é a vida que se agita em nós, com nossa sensibilidade, nossa afetividade e nossas emoções. Todo esse imaginário (...), todas essas histórias que nós nos contamos vai infinitamente mais longe como poder que agrega, que nossa razão (GESCHÉ, 2003, p. 139).

Para Gesché, a ficção - e por que não incluir aqui as superaventuras, mesmo que esse autor não tenha feito? - libera o pensar sobre o ser humano, graças a um desenvolvimento do imaginário, em que nada é impossível e deixado de fora. A ficção nos ensina mormente sobre o ser humano, às vezes, mais e melhor do que as teorias científicas (GESCHÉ, 2003, p. 139). Isto é, aquilo que o ser humano é ou pode ser, se descobre também por meio dos processos de invenção imaginativa. A tarefa hermenêutica do reconhecimento promove um conhecimento significativo do leitor com mundo acessado pela leitura, numa espécie de troca mútua, onde o texto ingressa na vida no momento no qual o leitor incorpora a personagem em seu interior. Há uma forma de saber e conhecer pelos símbolos implícitos e preservados nas narrativas fictícias e heroicas. Tal perspectiva - o argumento da expressão heroica -, em semelhança aos mitos, encontra ressonância na crítica dos limites da razão, como feita por Luc Brisson e Walter Meyerstein em Puissance et limites de la raison (cf. BRISON; MEYERSTEIN, 1995), de modo a ampliar o conhecimento para outras abordagens distintas da razão - como o elogio dionisíaco de Friedrich Nietzsche, o irracional de Rudolf Otto, ou a hierofania de Mircea Eliade: conhecimentos diretos e próprios de um modo de ser no mundo. Nesse sentido, é preciso ir além do discurso científico que se estabeleceu a partir de Bacon, Newton e Descartes, voltando-se contra o pensamento mítico (LÉVI-STRAUSS, 1978, p. 10-11).

Nessa direção, uma interpretação bourdieuana dos super-heróis ressalta que: "o fantástico e a imaginação satisfazem aspectos inconscientes dos indivíduos, permitem ultrapassar a vida cotidiana repressiva ou repetitiva, abre espaço para o extraordinário" (VIANA. In: REBLIN, 2008, p. 13). Mas, podemos evocar também a valorização do fantástico, na medida em que recuperamos o que o poeta Samuel Taylor Coleridge chamou de "fé poética", referindo-se ao movimento espontâneo da suspensão da incredulidade que a ficção reclama (COLERIDGE, 1991, p. 236). Se nos mantivermos apenas no primeiro nível de referencialidade da ficção dificilmente será possível captar 
as possibilidades que as ficções, incluindo aqui as superaventuras, projetam. Ora, podemos dizer que, levando em conta o caso dos super-heróis, o campo das experiências humanas pode ser ampliado se reconhecermos que tais superaventuras não são meros acessórios destinados a colorir a crueza preto e branca da realidade, mas se constituem como um acesso a ela por outro viés e possibilidade de sua recriação. Nesse sentido, pela via da imaginação se recupera aquilo que José Tolentino Mendonça chamou de uma "gramática integral do ser humano” (MENDONÇA. In: SPADARO, 2016, p. 6).

Antonio Blanch destacou em sua obra El hombre imaginário, que a compreensão que a literatura fornece do ser humano e do mundo não precisa ser desprezada, mas deve ser considerada como uma forma legítima de conhecimento antropológico. Segundo este autor, já passaram os tempos em que a reflexão sobre o ser humano se realizava exclusivamente nas altas esferas da abstração metafísica, mas ainda hoje as ciências e a filosofia precisam ser lembradas de que há outro caminho de acesso ao conhecimento do universo humano, que não é lógico nem físico, mas é simbólico e nem por isso é menos válido (BLANCH, 1995, p. 14). Essa posição é reforçada pelo crítico literário e pensador francês, Roland Barthes, que afirmou, em aula inaugural na Universidade de Sorbonne, que a literatura é o "fulgor do real". Ao fazer tal afirmação, Barthes ressaltou a importância da literatura frente outros modos de ver a realidade. Segundo ele, a ciência é grosseira, deixa escapar a sutileza que a vida se apresenta e a literatura corrige essa diferença. Se, por um lado, ela permite designar saberes possíveis, trabalhando nos interstícios da ciência, por outro lado, "o saber que ela mobiliza nunca é inteiro nem derradeiro: a literatura não diz que sabe alguma coisa, mas que sabe de alguma coisa; ou melhor: que ela sabe algo das coisas - que sabe muito sobre os homens" (BARTHES, 1978, p. 18-19).

Por isso mesmo, com suas peculiaridades, ao lado da literatura, as HQs como criação não são uma escapatória alienante da realidade, mas se estabelecem como um aparelho ótico, que dá ao leitor a possibilidade de perceber o que, talvez, sem elas, não observaria. Essa imagem é evocada por Antonio Spadaro a partir de uma citação de Marcel Proust: a literatura - e aqui incluímos as comic trips - é como "um laboratório fotográfico". Em resumo, essa metáfora (elaborada num tempo em que não existia a fotografia digital) sugere que somos incapazes de ver nossa própria vida e que, por isso, ela fica saturada de chapas fotográficas diante de uma inteligência que não desenvolveu a capacidade de revelá-las. Ou seja, uma das virtudes da 
literatura é a sua aptidão de permitir a experiência da própria vida (PROUST. In: SPADARO, 2016, p. 30-1).

Ainda, utilizando as palavras do escritor Henry James, podemos dizer que:

A casa da ficção não tem uma, mas um milhão de janelas - ou melhor, um número incalculável de janelas. Cada uma foi aberta ou pode ser aberta na vasta fachada, pela urgência de uma visão individual ou pela pressão de uma vontade própria. Como essas aberturas de tamanhos e formatos variáveis, debruçam-se todas juntas sobre a cena humana, seria de esperar que nos fornecessem uma maior semelhança informativa do que a encontrada. Quando muito, não passam de janelas, meros buracos numa parede inerte, desconexos a sombranceiro. Não são como portas com dobradiças abrindo-se diretamente para a vida. Mas tem uma característica própria: em cada uma encontramos uma figura com um par de olhos, ou, pelo menos, com binóculo, os quais frequentemente representam um instrumento único para a observação, assegurando ao sujeito que faz uso deles uma impressão diferente dos outros (JAMES, 2003, p. 161).

Nessa condição, sugere-se uma aproximação de ordem mitológica entre mitos fundantes e narrativas de superaventuras. Tal aproximação amplia os horizontes de interpretações dos atos e feitos das personagens. "Um super-herói”, segundo Iuri Reblin, "é muito muito mais que um desenho, uma animação ou um ator com um uniforme: é um símbolo que representa muito daquilo que o ser humano acredita, espera e também teme" (REBLIN, 2008, p. 48). Desse modo, tanto as origens e protótipos dos super-heróis, bem como, as suas inspirações, são aproximadas aos mitos e épicos antigos, parcialmente enquanto parte de um material cultural inconsciente (COOGAN, 2006, p. 116-125). Tal aproximação e origem dizem respeito aos processos de simbolizações e temporalidades específicas da superaventura.

\section{Simbolização incônscia}

Umberto Eco, em Apocalípticos e Integrados, ao dedicar um capítulo para o mito do Superman, trata a "mitização" como um processo de simbolização inconsciente (ECO, 2015, p. 239). É importante frisar esse conceito, uma vez que a aproximação entre super-herói e mitologia se dá, em grande escala, pela estrutura, de maneira simbólica - e o modo simbólico é comum na maioria dos teóricos em questão. No texto, Eco versa a respeito da desmitologização e hermenêutica bíblica, entre outras questões iconográficas de tradição e 
identidade religiosa. No entanto, o seu principal insight, a nosso ver, recai na presença mitopoética de estruturas mitológicas em figuras modernas, a despeito de qualquer confessionalidade religiosa. Se as personagens dos quadrinhos, nas figuras dos super-heróis, atraem adultos mais do que as mitologias poderiam atrair, justifica-se, segundo Eco, por que tais personagens "nos revelam alguns episódios altamente significativos" (ECO, 2015, p. 244). Super-heróis, em seus arquétipos heroicos e míticos nas HQs e cinema, são equivalentes aos mitos antigos. De certa forma, preservam a sobrevivência de mitos no imaginário atual. Aliás, diga-se de passagem, Croatto apontou que numa realidade diversa, os mitos podem: 1) se desintegrar; 2) passar à categoria de contos e fábulas ou; 3) ser recriados (CROATTO, 2001, p. 227). O paradoxo reside na reversão do uso das narrativas para uma indústria: não havia indústria financeira na época dos mitos. A despeito da discussão acerca da sociedade distraída e a necessidade inexorável do desvio da sobriedade - discutida pela escola de Frankfurt e, sobretudo, na filosofia da sensação - há, no mundo contemporâneo, a mediação das coisas fundantes com o moderno. Christoph Türcke, ao estender a sociedade do espetáculo para as sensações humanas diante do desejo inicial de inquietude, denomina de "retorno ao fundamento" a motivação desenfreada por novos estímulos narrativos. Na dinâmica da indústria cultural, pode-se inferir a renovação dos super-heróis enquanto um retorno revisado às coisas fundamentais, agora mediados pela tecnologia e novas linguagens. "A via de fuga que afasta a sociedade moderna em ritmo high-tech de suas origens arcaicas leva justamente de volta para elas" (TÜRCKE, 2010, p. 171). A criação, desse modo, é uma subcriação do fantástico, comparada à criação do divino. Para Eliade, os leitores de quadrinhos - e, por conseguinte, hoje, podemos acrescentar, os espectadores de animações e filmes ${ }^{11}$ - encarnam a trama a tal ponto que, quando contrariados por uma tomada de decisão ou acidente com algum personagem, "reagem violentamente e protestam, enviando milhares de telegramas aos autores dos comic strips e aos diretores dos jornais" (ELIADE, Mircea. Mito e Realidade, 2006, p. 159).

A diferença entre o Superman e os heróis das mitologias ou figuras tradicionais está no âmbito de uma civilização do romance. Enquanto imagens e figuras religiosas se mantinham fixas e imutáveis em suas formas

11 Neste caso, a título de exemplo, ganhou expressão o protesto e petição de fãs aos estúdios da Warner Bros pedindo o corte do diretor Zack Snyder para o filme Liga da Justiça (2017). Cf. http://www.adorocinema.com/noticias/filmes/noticia-136913/ Acessado em $09 / 03 / 2019$. 
e características eternas, Superman, por sua vez, seria um arquétipo: "a soma de determinadas aspirações coletivas, e, portanto, deve, necessariamente, imobilizar-se numa fixidez emblemática que a torne facilmente reconhecível - e é o que acontece com a figura do Superman" (ECO, 2015, p. 251). As aspirações coletivas são, a rigor, traços humanos na personagem - como a mortalidade -, uma vez que, se ele fosse imortal, deixaria de ser mito, pois estaria na categoria das divindades. O paradoxo narrativo de adentrar no cotidiano e, ainda assim, lidar com um tempo diferenciado, não isenta o universo do super-herói de uma cosmogonia própria. Aliás, tal cosmogonia própria poderia ser um dos traços encantadores, variando do leitor. Por isso, segundo Umberto Eco, as "estórias" do Superman se desenvolvem numa espécie de clima onírico, um imaginary tale, sem compromissos com edições anteriores, tramas finitas ou acontecimentos de outros roteiristas, tendo um recomeço livre a cada início de narrativa. Vale notar a parceria silenciosa, como uma cumplicidade tácita, da estratégia publicitária das HQs, renovando as "estórias" conforme o interesse do público e dos estúdios, enquanto a cosmologia própria é revivida, alternada, modificada e redirecionada em prol da vendagem e sucesso do material artístico.

Mircea Eliade, na coleção Symbolism, the Sacred, and the Arts, seção sobre a sobrevivência e a camuflagem do sagrado em narrativas atuais - parte desse material está também em Mito e Realidade -, escreveu:

Superman, um personagem fantástico, tornou-se extremamente popular, especialmente pela sua identidade dupla. Apesar de vir de um planeta destruído por uma catástrofe e possuir poderes prodigiosos, Superman vive modestamente na Terra sob o disfarce de um jornalista chamado Clark Kent. Ele é tímido, apagado e dominado por sua colega Lois Lane. Esta camuflagem humilhante de um herói, cujos poderes são literalmente ilimitados, revela um tema mítico muito conhecido. Em última análise, o mito do Superman satisfaz os anseios secretos do homem moderno, o qual, apesar de ciente de sua queda e limitação, sonha um dia ser uma pessoa excepcional, um herói (ELIADE, 1985, p. 45). ${ }^{12}$

12 "A fantastic character, Superman, has become extremely popular, especially because of his double identity; although coming from a planet destroyed by a catastrophe, and possessing prodigious powers, Superman lives on Earth in the modest guise of a journalist, Clark Kent; he is timid, unassertive, dominated by his colleague Lois Lane. This humiliating camouflage of a Hero whose powers are literally unlimited revives a well-known mythical theme. In the last analysis, the myth of Superman satisfies the secret longings of modern man who, though he knows that he is a fallen, limited creature, dreams of one day proving himself an 'exceptional person', a 'Hero'." 
A face do mito se apresenta no super-herói conforme os valores que o transcendem. A despeito do conhecimento ou não de narrativas míticas, sendo ou não adepto de alguma tradição religiosa atual, o reconhecimento da exemplaridade do herói é assimilado, consciente ou inconscientemente, pelas funções implícitas dos valores carregados pelo herói. Não por acaso o interesse pelos super-heróis cresce na medida em que essas estruturas de valores são reconhecidas e assimiladas. Entretanto, faz-se notar que tais valores não são exclusivos de Superman. Qualquer super-herói difundido na mídia de massa sustenta a mesma estrutura do mito do super-herói. As particularidades, estas sim, diferem a preferência do público por um ou outro personagem. Entre todos os super-heróis, Superman carrega o arquétipo mítico mais puro. Sua origem é de outro mundo - tal qual a motivação criação escatológica.

Em seus diários, Mircea Eliade, ao comentar sobre o prefácio de Elémire Zolla na obra, Il superuomo e $i$ suoi simboli nelle letterature moderne (vol. 5, Florence, 1977), surpreendeu-se com a relação inversamente proporcional do desinteresse pelo cristianismo e o crescente interesse pelo mito de um super-homem. "Eu aprendi com Disraeli, em seu romance Lothair, de 1870, previu uma ascensão de um tipo de culto ao super-homem proporcional ao declínio do cristianismo, tendo como corolários uma exaltação neopagã da raça, bem como o declínio de uma cultura baseada em livros" (ELIADE, 1989b, p. 268). Evidentemente, aqui, Eliade não se refere ao personagem Superman - de fato, sua preocupação repousa na doutrina ariana preponderante na cultura alemã e, também, na aproximação inapropriada de Friedrich Nietzsche ao Nationalsozialismus, aproximação feita por sua irmã Elisabeth Förster-Nietzsche, casada com Bernhard Förster, um nacionalista alemão e antissemita, tornando o irmão no filósofo de referência da Alemanha nazista ${ }^{13}-$, mas anuncia duas categorias estruturantes do personagem e de sua condição cultural: Superman, de certo modo, remete alguns perfis emancipais humanos - independência da religião - e, por sua vez, tais narrativas escapam dos livros e se tornam vivas em quadrinhos e, posteriormente, telas de TV e cinema. O declínio de uma cultura ancorada em livros é acompanhado pela ascensão de uma cultura de massa, televisiva e cinemática. A marca da nossa época, além da laicidade e da camuflagem do sagrado na própria laicidade, lida com a cultura de massa numa troca simbólica de valores interiores e valores

13 Para uma boa resolução desse infortúnio, cf. Bataille, Georges. Sobre Nietssche: Vontade de Chance. Suma Ateológica, Vol III. Belo Horizonte: Autêntica Editora, 2017. 
capitais, mantendo, assim, indústrias do entretenimento operantes e vitoriosas diante da concorrência diária por narrativas ideais e produtos principais.

A universalidade do super-herói ecoa nos sentimentos de humanos que lidam com a queda interior, as limitações humanas, o sonho de ser alguém excepcional, o ideal de tornar-se um herói. O enredo comunica por temas míticos - os mesmos fundos estruturantes da ansiedade e incerteza humana. Superman é, em suma, um mito, i.e., "uma narrativa metalinguística que fala ao consciente e ao inconsciente humano e, ao mesmo tempo, visa preservar a coesão social e reafirmar a identidade de um grupo, resguardar valores, fornecer um equilíbrio e, em última instância, dar sentido à existência” (REBLIN, 2008, p. 97). Tudo isso não salva o super-herói de algumas contradições intrínsecas de sua existência, como o sucesso de uma empresa em prol de uma simbolização inconsciente. ${ }^{14}$ Entretanto, se o símbolo opera de maneira inconsciente - e, por isso, é usado pela empresa mantenedora do personagem - há outro elemento fundamental à existência do personagem que escapa a todos envolvidos no processo: o tempo do voo heroico.

\section{Temporalidade}

Os três perfis sugeridos por Iuri Reblin, a saber, simbolo do desejo de poder, símbolo das esperanças messiânicas e símbolo do Destino Manifesto, propõem o símbolo como uma linguagem própria da religião expressa também na mitologia dos super-heróis. A noção do ser humano como um ser simbólico - "deveríamos definir o homem como animal symbolicum e não como rationale" (CASSIRER, 1985, p. 163) - promove um saber voltado à reflexão de caráter hermenêutico para o fenômeno da religião e dos super-heróis. O símbolo religioso, como trabalho pela Teologia Sistemática do século XX (entre alguns, Paul Tillich, Rubem Alves, Jürgen Moltmann e Rudolf Bultmann), oferece um rompimento com o mundo ordinário, uma ficção no real para o pensamento de outras realidades. Nesse sentido, um dos caminhos de aproximação entre mito e superaventura, entre religião e super-heróis, inicia, em nosso estudo, pelo símbolo e, justamente por isso, se insere num dos temas mais difíceis da fenomenologia: a experiência temporal enquanto

\footnotetext{
14 A história de Joe Shuster e Jerry Siegel, remunerados com U\$150 dólares pelos direitos do Superman, cedidos à DC Comics, garantindo à empresa lucros incontáveis, contrasta ironicamente os superpoderes do personagem com as contradições do mundo real, a saber, o destino ignorado de seus criadores.
} 
motor primeiro da experiência religiosa e, portanto, de outras exteriorizações saturadas de sentidos.

Em seus diários e palestras - fontes igualmente primárias de conteúdo -, Mircea Eliade sempre incluía uma noção de necessidade por narração. Apesar de nunca ter aprofundado propriamente essa noção, ele escreveu: "eu já realizei inúmeras alusões à necessidade existencial de se ouvir ou ler um conto, seja ele um mito, um conto de fadas, uma história ou um romance" (ELIADE, 1989b, p. 278). Há um "valor exemplar" do mito na narração do romance e do texto de ficção. Tal valor preserva na consciência modelos e modos de vivência essenciais para a existência humana. Para Eliade, no prefácio da sua obra Bosque Proibido, "a narração constitui uma experiência literária autônoma e irredutível; e isto pela simples razão de que a narração épica corresponde, na consciência do homem moderno, à mitologia na consciência do homem arcaico" (ELIADE, 1963, p. 6). Em sua condição de homo religiosus, o homem moderno, assim como o homem arcaico, não pode existir sem mitos. O mito se refere às narrações exemplares: pois qualquer mito que relata uma "estória" ou conto de uma criação, diz-nos como algo veio a ser. Desse modo, a narração não é apenas central, mas, antes de qualquer acepção, a narração é elementar, de modo a possibilitar a sobrevivência de valores exemplares pelo tempo. "A narração só readquire sua dignidade metafísica se os acontecimentos que descreve correspondem de um modo misterioso e sem a consciência do autor - aos acontecimentos exemplares da mitologia" (ELIADE, 1963, p. 7). Há uma estreita relação entre os valores exemplares da mitologia e da literatura. O romance narrativo, a narração em si, possui uma função metafísica, pois nos diz algo que aconteceu e que tal acontecimento influi na existência de certas pessoas; evidentemente, esse sentido metafísico não foi significado por gerações realistas e psicologizantes (que atribuíram importância à análise psicológica, espectral e psicomental do texto), mas a narração do romance, com sua dimensão metafísica, revela significados inesperados e esquecidos para a contemporaneidade e para o leitor sofisticado.

O que está em questão aqui é a mesma intuição encontrada em Tempo e Narrativa, de Paul Ricoeur: a narrativa inaugura a experiência humana do tempo. O tempo, por sua vez, devido à narratividade, torna-se humano. A própria experiência do tempo é uma experiência heterogênea, com múltiplos recortes orientados por uma abertura ficcional na existência humana. Há, dessa maneira, uma "saída do Tempo", saída produzida pela leitura, em 
especial a leitura de romances - mas também pela experiência religiosa, a saber, a dicotomia entre tempo sagrado e tempo profano: um tempo essencialmente diferente da duração profana que o antecede. Segundo Eliade, o distanciamento temporal promovido pela leitura "é o que mais aproxima a função da literatura da [função] das mitologias" (ELIADE, 2006, p. 164). A saída do tempo histórico ${ }^{15}$ mergulha o leitor ou espectador num tempo fabuloso e trans-histórico. Pela estrutura das personagens e a característica da trama, há conflitos entre um tempo estranho e um imaginário operante, denotando à narrativa um tempo específico, original e exclusivo de sua constituição. Um romance, em suas palavras, "não tem acesso ao tempo primordial dos mitos; mas, na medida em que conta uma história verossímil, o romancista utiliza um tempo aparentemente histórico e, não obstante, condensado ou dilatado, um tempo que dispõe, portanto, de todas as liberdades dos mundos imaginários" (ELIADE, 2006, p. 164).

Uma das diferenças da literatura para as demais expressões artísticas reside no conflito intenso e explícito contra o tempo histórico. Há um anseio cíclico por uma renovação temporal diferenciada do tempo social do trabalho. Ao final de Mito e Realidade, Eliade desconfia se a experiência extática e imaginária do tempo não-histórico seria, algum dia, extirpada. "Enquanto subsistir esse anseio", conclui ele, "pode-se dizer que o homem moderno ainda conserva pelo menos alguns resíduos de um 'comportamento mitológico”" (ELIADE, 2006, p. 165). Nesse comportamento, se revela um desejo primordial por um reencontro com as originais interiores. A repetição de uma vivência inaugural é vivida na leitura e releitura de narrativas fundantes - aquelas que oferecem sentido primordial ao leitor. ${ }^{16}$ Evidentemente a repetição aqui não é intencionada como o arquétipo da repetição cosmogônica das religiões (ELIADE, 1997, p. 484-485). Trata-se de uma repetição mais vital, não confessional, solidária com a sequência narrativa do leitor e espectador diante da contemplação da superaventura. Se nos mitos religiosos se busca reviver a primeira vez de um passado irrecuperável, na tentativa de não se perder no tempo, nas superaventuras periodicidade torna um tempo mítico presente. A contemplação de

15 Não confundir com a negação da historicidade; para mais informações, cf.: Guimarães, André Eduardo. O Sagrado e a História: Fenômeno religioso e Valorização da História à Luz do Anti-Historicismo de Mircea Eliade. Porto Alegre: EDIPUCRS, 2000.

16 Para o tema de textos fundantes - a força das estórias -, consultar Puchner, Martin. The Written World: The Power of Stories to Shape People, History, Civilization. New York: Penguin Random House LLC, 2017. 
superaventuras, em busca de um tempo próprio e original, pela força inconsciente da simbolização que liga o leitor e espectador ao seu superherói favorito, o torna contemporâneo do herói. Trata-se de uma atitude geral e comum do ser humano arcaico diante de suas narrativas fundantes. Não se espera de um fã de quadrinhos a mesma disposição de um adepto religioso para com os seus textos importantes. No entanto, o recorte não homogêneo do tempo pela experiência literária preserva traços míticos em personagens laicizadas e instaura um tempo que antes foi um tempo mítico, "aquele tempo", o Grande Tempo, in illo tempore, tempo de revelação. Há uma correspondência significativa entre existência e essência a ponto de, segundo Van der Leeuw, "basta conhecer o mito para compreender a vida" (LEEUW, apud ELIADE, 1997, p. 489). O poder da arte revela aspectos da vida e, no caso dos fãs de quadrinhos, as narrativas promovem uma dobra temporal comunicando importâncias, anseios e valores, simbolicamente, de modo que o leitor e espectador podem dispor de outra abordagem literária para compreender a vida. Tal abordagem não se distancia em diferença da literatura como um todo: ela é, particularmente, mediada pela contemplação dos atos e feitos, a um tempo próprio, de super-heróis.

Retomando o que até aqui foi trabalhado, para Umberto Eco, ao sugerir a hipótese da simbolização incônscia - e se perguntar qual o traço mitológico por excelência do personagem Superman - infere uma noção confusa do tempo como a condição de credibilidade da narrativa de caráter mitológica. "O Superman só se sustenta como mito se o leitor perder o controle das relações temporais e renunciar a raciocinar com base nelas, abandonando-se, assim, ao fluxo incontrolável das estórias que lhe são contadas e mantendo-se na ilusão de um contínuo presente" (ECO, 2015, p. 260). Há um exercício de presentificação contínua diante do tempo diferenciado. Um exercício inconsciente e, ao mesmo tempo, existencial. Desse modo, o sucesso do personagem é também o seu destino: um constante projeto que acontece simbolicamente na projeção do leitor e espectador como resolução dos seus anseios, ciente de sua queda e limitações, sonhando um dia ser um ser exemplar, um herói: "A existência de uma liberdade, da liberdade de fazer projetos, do dever de fazêlos, da dor que esse projetar comporta, da responsabilidade que dele provém, e enfim da existência de toda uma comunidade humana cuja progressividade se baseia sobre o meu projetar" (ECO, 2015, p. 261). 


\section{Considerações finais}

O percurso do artigo procurou traduzir um olhar para os super-heróis que possibilitasse uma reflexão a partir de uma aproximação à estrutura dos mitos, guardadas as devidas diferenças. Desse modo, procuramos demonstrar como esses personagens são, de algum modo, uma variação mitológica, uma forma de criação imaginativa que recupera elementos míticos recriandoos. Desse modo, verificamos que é possível, mesmo que os super-heróis não correspondam exatamente às características do monomito, identificálos em sua função arquetípica. Em outras palavras: é plausível identificar as raízes mitológicas das comic strips. Como procuramos deixar claro, essa abordagem se inscreve numa perspectiva de recuperação da importância da imaginação nascida da reflexão sobre os limites da razão. Assim, foi possível reconhecer que há uma intenção, mesmo que inconsciente - e, muitas vezes, a serviço de uma indústria cultural de entretenimento - de "um ultrapassar das limitações constituídas por uma sociedade repressiva, que inclusive reprime a imaginação e a fantasia, o extraordinário, em favor da razão instrumental, do rendimento, da seriedade" (VIANA In: REBLIN, 2008, p. 14). A simbolização acontece num tempo primordial de conhecimento e reconhecimento do leitor e espectador. Aqui, a ideia de Jean-Pierre Sarrazac, acerca dos escritos dramatúrgicos, pode ser aplicada: em grande medida, seu trabalho é estender o jogo dos possíveis (SARRAZAC, 2000, p. 79). Dessa forma, podemos entender as superaventuras como um espaço de elaboração da existência humana também a partir do ângulo de suas possibilidades ainda não exploradas.

Por meio da utilização criativa dos recursos da imaginação, elas tornam possível, como ressalta Steiner, uma contrafactualidade imprescindível (STEINER, 1998, p. 102), mas não só isso; essas narrativas constituem outra tessitura temporal que permite uma experiência de deslocamento. $\mathrm{O}$ desenrolar da trama se dá numa dialética de criação e descobrimento, de modo que a representação possibilita o vislumbre de outra ordem que não era possível entrever. Seu potencial se relaciona a uma ordenação como sequência e estabelecimento de relações entre os acontecimentos, a uma explicação e decifração dos episódios, mas também a uma força metafórica que reescreve a realidade por meio da suspensão de um primeiro nível de referencialidade. Ou seja, o mundo da ficção não é simples constatação, mas é um convite a descobrir um novo sentido. Ultrapassando as leis e conceitos, coloca o humano - por meio do super-humano - em circunstâncias que o 
ilumina, desvelando e criando assim um universo de sentido que redireciona o modo de ser no mundo (SPADARO, 2002, p. 47). Por conseguinte, como buscamos demonstrar, os super-heróis, com seus voos, superpoderes e virtudes, devolvem ao humano características que são próprias do humano: a capacidade de sonhar e a possibilidade de ser alguém melhor.

\section{Referências}

ALLEN, Douglas. Myth and Religion in Mircea Eliade. New York: Routledge, 1998, 384p. BARTHES, Roland. Aula. São Paulo: Cultrix, 1978.

BATAILLE, Georges. Sobre Nietzsche: Vontade de Chance. Suma Ateológica, v. III. Belo Horizonte: Autêntica Editora, 2017.

BENJAMIM, Walter. “A obra de arte”. In: Os Pensadores - Textos escolhidos. São Paulo: Abril Cultural, 1983.

BLANCH, Antonio. E1 hombre imaginário: una antropología literaria. Madrid: Universidad Pontificia de Comillas, 1995.

CASSIRER, Ernest. Linguagem e mito. São Paulo: Perspectiva, 1985.

COLERIDGE, Samuel Taylor. Biographia literária ovvero schizzi biograficci della mia vita e opinioni ltterarie. Roma: Editori Reuniti, 1991.

COOGAN, Peter. Superhero: The Secret Origin of a Genre. Austin: Monkeybrain, 2006.

CROATTO, José Severino. As linguagens da experiência religiosa: uma introdução à fenomenologia da religião. São Paulo: Paulinas, 2001.

DORFMAN, Ariel; JOFRÉ, Manuel. Super-Homem e seus amigos do peito. Rio de Janeiro: Paz e Terra, 1978.

DUCAN, Randy. SMITH, Matthew. The Power of Comics: History, Form and Culture. New York: The Continuum Publishing Company, 2009.

ECO, Umberto. Apocalípticos e Integrados. São Paulo: Perspectiva, 2015.

ECO, Umberto. O Super-Homem de Massa. São Paulo: Perspectiva, 1978.

ELIADE, Mircea. Imagens e símbolos: ensaio sobre o simbolismo mágico-religioso. São Paulo: Martins Fontes, 2002, 178p.

ELIADE, Mircea. Journal I: 1945-1955. Chicago: The University of Chicago Press, 1990, 219p. ELIADE, Mircea. Journal II: 1957-1969. Chicago: The University of Chicago Press, 1989, 343p. ELIADE, Mircea. Journal III: 1970-1978. Chicago: The University of Chicago Press, 1989b, 370p. ELIADE, Mircea. Journal IV: 1979-1985. Chicago: The University of Chicago Press, 1990, 167p. ELIADE, Mircea. Mito e Realidade. São Paulo: Perspectiva, 2006. 
ELIADE, Mircea. Ordeal by Labyrinth: Conversations with Claude-Henri Rocquet. Chicago: University of Chicago Press, 1982.

ELIADE, Mircea. Symbolism, the Sacred, and the Arts. New York: The Continuum Publishing Company, 1985, 185p.

ELIADE, Mircea. Tratado de História das Religiões. Lisboa: Edições Asa, 1997.

FERREIRA, João Leonel. "A Bíblia como literatura: lendo as narrativas bíblicas." In: Correlatio, n. 13, 2008, p. 4-22.

FLORENCE, Jean; RENARD, Marie-France (dir.). La littérature: réserve du sens, ouverture de possibles. Bruxelles: Publications des Facultés universitaires Saint-Louis, 2000.

FRYE, Northop. O código dos códigos: a Bíblia e a literatura. São Paulo: Boitempo, 2004.

GESCHÉ, Adolphe. O sentido. São Paulo: Paulinas, 2003.

JAMES, Henry. A arte do romance: antologia de prefácios. São Paulo: Globo, 2003.

JEWETT, Robert; LAWRENCE, John Shelton. The American Monomyth. New York: Doubleday, 1977.

JEWETT, Robert; LAWRENCE, John Shelton. The Myth of the American Superhero. Grand Rapids, Michigan: Eerdmans, 2002.

LÉVI-STRAUSS, Claude. Mito e significado. Lisboa: Edições 70, 1978.

MIETTINEN, Mervi. Superhero Comics and the Popular Geopolitics of American Identity. University of Tampere. School of Language, Translation and Literary Studies. Licenciate's Dissertation in English Philology. March 2011.

MORRISON, Grant. Supergods: What Masked Vigilantes, Miraculous Mutants, and a Sun God from Smallville Can Teach Us About Being Human. New York: The Random House Publishing Group, 2011.

PUCHNER, Martin. The Written World: The Power of Stories to Shape People, History, Civilization. New York: Penguin Random House LLC, 2017.

REBLIN, Iuri Andréas. A superaventura: da narratividade e sua expressividade à sua potencialidade teológica. Tese (doutorado). Orientadora: Laude Erandi Brandenburg. São Leopoldo: EST, 2012, 257s.

REBLIN, Iuri Andréas. Para o alto e avante: uma análise do universo criativo dos superheróis. Porto Alegre: Asterisco, 2008.

RENNIE, Bryan S. Reconstructing Eliade. New York: State University of New York Press, 1996, 308p.

REYNOLDS, Richard. Superheroes: a Modern Mythology. Jackson: University Press of Mississipi, 1992.

SARRAZAC, Jean-Pierre. Écritures contemporaines dramatiques: le jeu des possibles. In: FLORENCE, Jean; RENARD, Marie-France (dir.). La littérature: réserve du sens, ouverture de possibles. Bruxelles: Publications des Facultés universitaires Saint-Louis, 2000. 
SPADARO, Antonio. A che cosa "serve" la letteratura? Roma: La civilità Cattolica, 2002. SPADARO, Antonio. O batismo da imaginação: a experiência da palavra criativa. Lisboa: Paulinas, 2016.

STEINER, George. Errata. Récite d'une pensée. Paris: Gallimard, 1998.

TÜRCKE, Christoph. Sociedade Excitada: Filosofia da Sensação. Campinas: Ed. Unicamp, 2010, 323p.

VIANA, Nildo. Heróis e super-heróis no mundo dos quadrinhos. Rio de Janeiro: Achiamé, 2005.

VIEIRA, Marcos Fábio. "Mito e herói na contemporaneidade: as histórias em quadrinhos como instrumento de crítica social” In: Contemporânea, n. 8, v. 1, 2007.

Submetido em: 19-10-2019

Aceito em: 28-10-2019 